\title{
30. THE CLAY-MINERALOGICAL RECORD OF THE LAST 10 MILLION YEARS OFF NORTHEASTERN AUSTRALIA ${ }^{1}$
}

\author{
Hervé Chamley, ${ }^{1,2}$ Christian Robert, ${ }^{3}$ and Daniel W. Müller ${ }^{4,5}$
}

\begin{abstract}
Clay mineral assemblages for the last 10 m.y. are described for Site 823 , at $16^{\circ} \mathrm{S}$ in the Queensland Trough, to the northeast of Australia. Largely unaffected by diagenetic influences, these mostly express the evolution of northeastern Australian continental environments during the late Neogene: (1) beginning during the late Miocene at about $7.0 \mathrm{Ma}$ is an increase of illite derived from rocky substrates at the expense of smectite from deeply weathered soils; this increase was the result of increasing aridity in the Australian interior and globally cooler temperatures, associated with increases in Antarctic glaciation; (2) concomitant and further increases of kaolinite fluxes to the Queensland Trough during the late Miocene-early Pliocene largely reflect an increase in rainfall in northeastern Australia; (3) increases in both soil- and rock-derived minerals probably intensified as a result of late Neogene uplift of the eastern highlands; (4) clay-mineral associations during the Pliocene and Pleistocene display minor variations only and probably resulted in part from differential settling and sea-level changes; (5) similar trends of clay-mineral variations occur at both ODP Site 823 and DSDP Site 588 (Lord Howe Rise). Less abundant kaolinite relative to illite at Site 588 nevertheless suggests a southward decrease of continental humidity and/or of the eastern highlands uplift; (6) influences of global climate and oceanic and atmospheric circulations on clay-mineral associations dominated during the late Miocene and were progressively replaced by influences of more regional environmental variations during the Pliocene and especially the Pleistocene.
\end{abstract}

\section{INTRODUCTION}

Leg 133 was devoted to the drilling of the northeastern Australian margin, which represents the largest neritic carbonate area to have developed on Earth during the late Cenozoic (i.e., Queensland and Marion plateaus, Great Barrier Reef; Fig. 1). A major objective of Leg 133 was to define the evolution of the carbonate platforms and their relationships to adjacent basins (Davies, McKenzie, Palmer-Julson, et al., 1991). The main basin in this area is the Queensland Trough, which is located between the Great Barrier Reef and the Queensland Plateau (Figs. 1 and 2). Drilling of the plateaus and the Australian slope permitted the recovery of a carbonate platform series, whereas drilling the trough permitted an investigation of the basinal sedimentary filling for paleoceanographic history and correlation with the margin and the plateau.

Neogene and Quaternary sedimentation in the Queensland Trough resulted from carbonate accumulation from pelagic productivity and benthic life on adjacent platforms, and fine siliciclastic material derived principally from Australia.

Clay mineralogy is a reliable tool for the study of paleoenvironmental conditions as expressed by siliciclastic sedimentary fractions (e.g., Chamley, 1989). Clay-mineral assemblages of the upper Cenozoic sediments of Site 823 in the Queensland Trough aided in the recognition of terrigenous source-areas, climatic changes on the Australian continent, intensities of circulation, and variations in sea level. Site 823 consists of $1011 \mathrm{~m}$ of uppermost middle Miocene (10 Ma.) to upper Quaternary hemipelagic ooze and gravity flow deposits from the deepest part of the central-western Queensland Trough. Carbon isotope data were used to document the discussion. The clay mineralogical data from Site 823 have been compared with

\footnotetext{
'McKenzie, J.A., Davies, P.J., Palmer-Julson, A., etal., 1993. Proc. ODP, Sci. Results, 133: College Station, TX (Ocean Drilling Program).

${ }^{2}$ Dynamique Sédimentaire et Structurale, URA 719 CNRS, Université de Lille I, 59655 Villeneuve d'Ascq Cedex. France.

${ }^{3}$ Géologie du Quaternaire, UPR 120 CNRS, Luminy, Case 907, 13288 Marseille Cedex 9, France.

${ }_{5}^{4}$ Geologisches Institut, ETH Zentrum, 8092 Zü, Switzerland.

${ }^{5}$ Now at: Wolfgaghof 13A, 9014 ST. Gallen, Switzerland.
}

a few results from Sites $819,820,821,824$ and 825 (mostly of Pleistocene age) to help in understanding the sources of the fine sedimentary fraction (Figs. 1 and 2). Comparison of clay-mineral data between Site 823 (Queensland Trough) and Site 588 on the northern Lord Howe Rise $\left(26^{\circ} \mathrm{S}\right)$ off eastern Australia (Stein and Robert, 1985; Table 1) permitted a better constraint of the evolution of Australian continental environments, and its relation to climate.

Both Sites 823 and 588 were drilled in intermediate water depths (1638 and $1533 \mathrm{~m}$, respectively) off the eastern Australian continental margin. Site 823 is located at about $16^{\circ} \mathrm{S}$, east of Queensland, where local development of tropical rainforests in the highlands has been associated with pedogenic formation and erosion of kaolinite. Rainforests are replaced inland by dry sclerophyll vegetation (Griffin et al., 1968; Walter, 1971; Flenley, 1981). By contrast, Site 588, drilled on Lord Howe Rise at $26^{\circ} \mathrm{S}$, is under major influence of westerly winds and detrital supply from arid to subarid areas, where dry Eucalyptus forests grade westward to grassland, scrub, and salt bush (Glasby, 1971; Walter, 1971; Kennett and Von der Borch, 1985; Stein and Robert, 1985). In eastern Australia, suitable drainage conditions ensure the formation of kaolinite in deeply weathered soils, while smectite genesis is favored in poorly drained, low-relief areas, as well as in semi-arid continental hinterland. In central Australia, arid conditions prevent weathering and soil formation, and strong winds mostly erode illite from crystalline substrates together with reworked clay minerals from paleosoils and sediments, including kaolinite (Griffin et al., 1968; Pédro, 1984; Chamley, 1989).

\section{METHODOLOGY}

Sixty samples were taken at fairly regular intervals from the cores of Holes $823 \mathrm{~A}, 823 \mathrm{~B}$, and $823 \mathrm{C}$, with a higher density in upper Miocene sediments (one sample per core or two cores; Fig. 3).

The clay-mineral data were obtained using X-ray diffraction (XRD) of the micrometer-size fraction. Samples were decalcified with $0.2 \mathrm{~N} \mathrm{HCl}$, and the $\mu \mathrm{m}$-size fraction was separated by settling. Oriented mounts were prepared on glass slides and were scanned three times $\left(\mathrm{Cu}, \mathrm{K}_{\mathrm{a}}\right.$ radiation): from $2.5^{\circ}$ to $28.5^{\circ} 2 \theta$ on untreated samples, from $2.5^{\circ}$ to $14.5^{\circ} 2 \theta$ on glycolated samples, and from $2.5^{\circ}$ to $14.5^{\circ} 2 \theta$ 


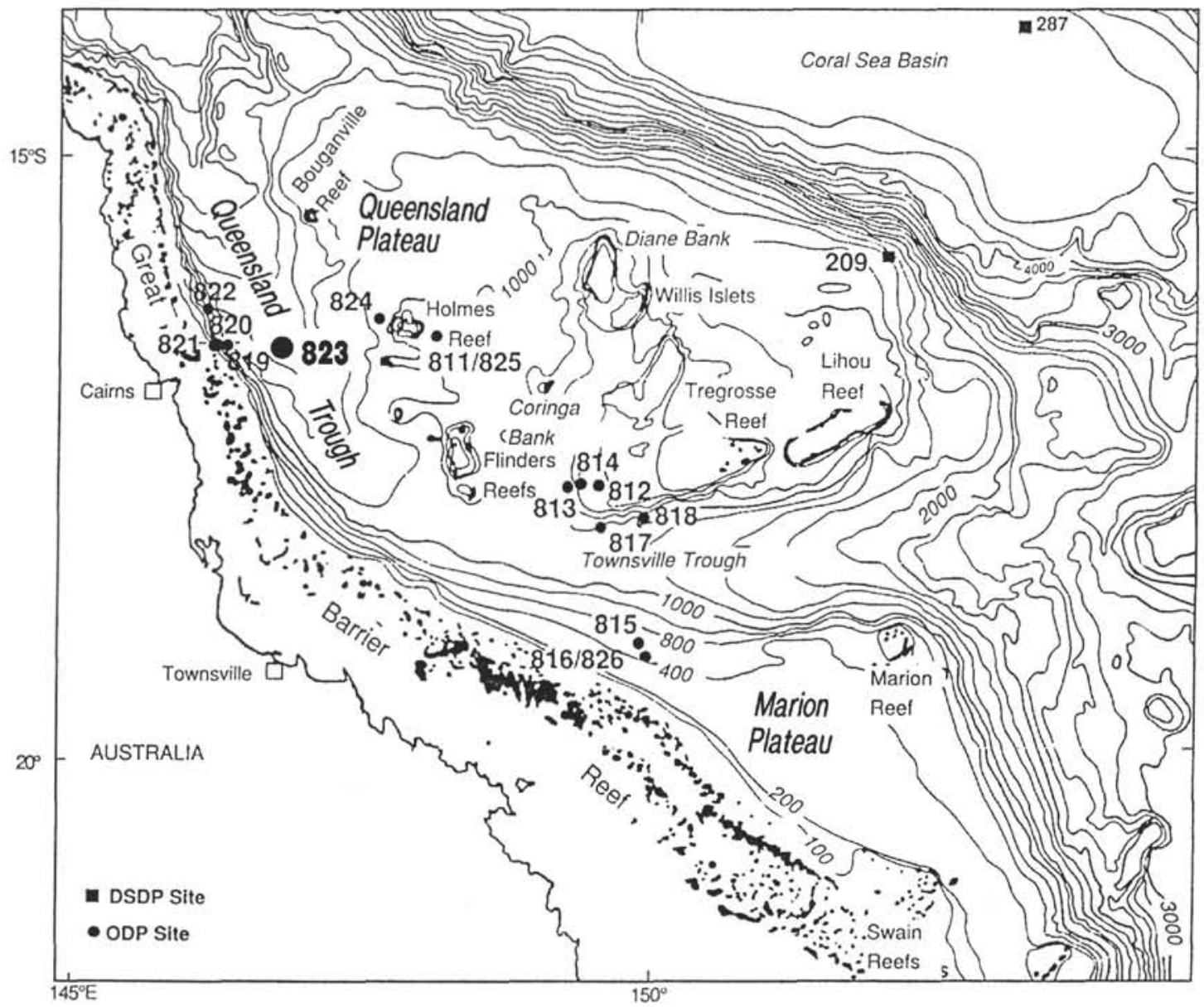

Figure 1. Map of northeastern Australian margin showing location of Site 823 and other Leg 133 sites. Bathymetry in meters (after Davies, McKenzie, Palmer-Julson, et al., 1991).

on samples heated for $2 \mathrm{hr}$ at $490^{\circ} \mathrm{C}$. Analytical techniques, determination, and quantitative estimation of clay minerals are detailed in Chamley and Debrabant (1984) and Holtzapffel (1985). Analytical uncertainties in the clay-mineral abundances are 5\% (absolute) for abundances above 20\%, 3\% (absolute) for abundances between 5\% and $20 \%$, and $2 \%$ (absolute) for abundances below $5 \%$. X-ray traces also indicate the presence of nonphyllosilicate minerals (especially quartz and feldspar), whose abundances cannot be quantified using this technique. These minerals are described as "rare" or "common" based on the intensity of their principal characteristic peak.

Additional information is provided by four indexes calculated from the ratio of the peak heights, measured on the X-ray trace of the glycolated samples:

Smectite/illite (S/I): 17/10Å peak height ratio.

Kaolinite (+ chlorite)/illite (K/I): 7/10 peak height ratio.

Kaolinite (+ chlorite)/smectite (K/S): 7/17 $\AA$ peak height ratio.

Chlorite/illite (C/I): $4.7 / 5 \AA$ peak height ratio.

For stable carbon isotope analysis, the sediment was dried and ground finely in a mortar and roasted in vacuo at $400^{\circ} \mathrm{C}$ for $60 \mathrm{~min}$ to remove organic material. The reaction of the carbonate and the production of $\mathrm{CO}_{2}$ gas from the carbonate material (see McCrea, 1950) occurred on-line at $82^{\circ} \mathrm{C}$ using an automated carbonate extraction apparatus. Samples were reacted in a common acid bath of $100 \%$ $\mathrm{H}_{3} \mathrm{PO}_{4}$. The evolved gas was analyzed using a VG Isogas-PRISM triple collector mass spectrometer. The errors are $0.08 \%$ for $\delta^{13} \mathrm{C}$.

\section{RESULTS AT SITE 823}

\section{General Data}

The following minerals are recognized (Fig. 3) in the carbonatefree clay fraction in decreasing order of abundance:

Smectite: ubiquitous, $45 \%$ to $85 \%$ of clay minerals, mean $60 \%$;

Kaolinite: ubiquitous, $10 \%$ to $35 \%$, mean $25 \%$;

Illite: ubiquitous, $3 \%$ to $18 \%$, mean $10 \%$;

Random mixed-layers: ubiquitous, mostly chlorite-smectite types, accessorily illite-smectite type; traces to $10 \%$ of the clay fraction, mean $5 \%$;

Chlorite, locally present but frequent, $0 \%$ to $5 \%$; in Units IV to VII, episodically above; and palygorskite, locally present in Subunit IIIA, $0 \%$ to $5 \%$.

The major clay minerals are medium- to highly crystalline, with smectite being more often medium-crystalline and kaolinite and illite frequently highly crystalline. Nonphyllosilicate minerals in the less than $2 \mu \mathrm{m}$ fraction include ubiquitous, rare-to-common quartz, frequently associated with rare-to-common feldspars, and very local (Unit I), rare gibbsite.

The general trend of clay-mineral succession at Site 823 consists of a late Miocene decrease of the smectite abundance, associated with a rapid increase of kaolinite, and followed by a more progressive augmentation of illite (Fig. 3, left ; Table 2). 


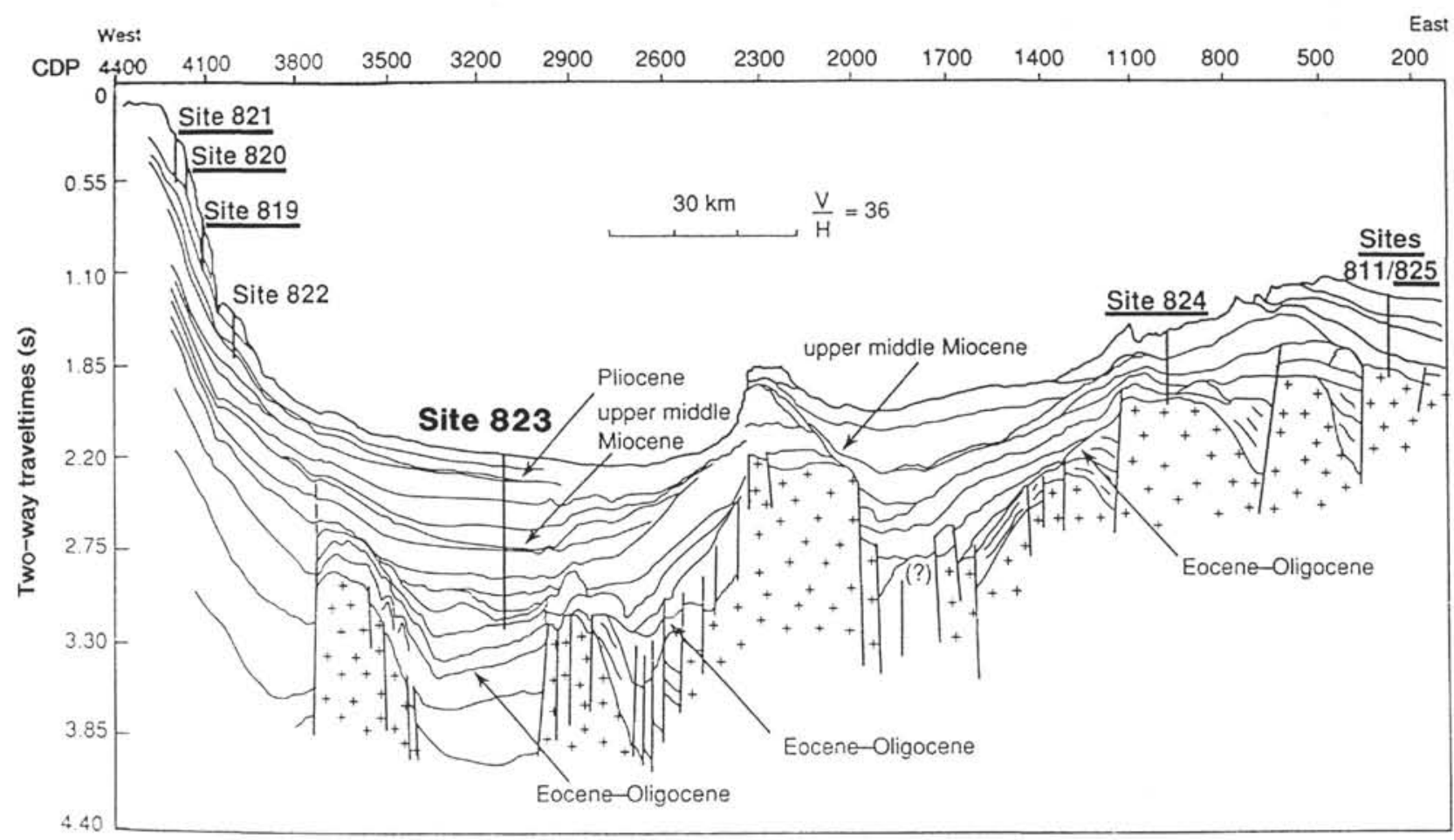

Figure 2. Schematic section of Site 823 and other Leg 133 sites across Queensland Trough (from Davies, McKenzie, Palmer-Julson, et al., 1991).

Generally, no close relationship was seen between the clay mineralogy and the lithology. The relative abundances of the principal minerals (smectite, kaolinite and illite) are generally not related to specific lithofacies: nannofossil ooze, hemipelagic ooze, chalk, clayey nannofossil ooze or foraminifer-ooze to chalk, silty to sandy chalk, mixed clayey-bioclastic-micritic sediment, and so forth. However, some relationships locally exist between the clay mineral and the lithofacies distribution (Fig. 3) as follows:

1. Some whitish, carbonate-rich, pelagiclike sediments exhibit a relative increase of smectite relative to illite and chlorite. This is the case of Samples 133-823B-31X-2, $129 \mathrm{~cm}$, or -33X-3, $128 \mathrm{~cm}(60 \%$ to $65 \%$ smectite) intercalated between more clay-rich levels at 133 $823 \mathrm{~B}-29 \mathrm{X}-2,135 \mathrm{~cm}$, and $-35 \mathrm{X}-3,90 \mathrm{~cm}$ (50\% to $55 \%$ smectite); and of the chalks in Samples 133-823C-1R-5, $36 \mathrm{~cm}$, and 2R-4, $64 \mathrm{~cm}$ (60\% to $70 \%$ smectite), located beneath the olive mudstones of Cores $133-823 \mathrm{~B}-80 \mathrm{X}$ to $-82 \mathrm{X}$ ( $45 \%$ to $60 \%$ smectite). Such mineralogical differences may reflect differential settling processes preferentially depositing small, light, buoyant smectite in pelagic sediments (see Gibbs, 1977).

2. Certain redeposited sediments are marked by the presence of chlorite, which is locally associated with feldspar, and/or increased kaolinite and quartz contents, compared to the surrounding hemipelagic deposits. This is especially the case of the turbidite at 133$823 \mathrm{~B}-17 \mathrm{X}-2,125 \mathrm{~cm}$, in Unit II, and of the debris flows in Subunits IIIA and IIIC, compared to the pelagic Subunit IIIB (Fig. 3). Such lithologically controlled mineralogical changes may reflect deposition of the sediments in two stages: (1) initial deposition in proximal areas, where large and relatively dense minerals (such as quartz, feldspars, chlorite, and kaolinite) preferentially settle and (2) subsequent reworking and redeposition of these minerals to more distal areas usually enriched in the smaller and more slowly settling smectite (see Chamley, 1989). Notice that the differences between redeposited and hemipelagic deposits are by no means systematic, with some facies of both types sometimes being closely associated and nevertheless devoid of clay-mineral differences indicative of

Table 1. Site characteristics.

\begin{tabular}{lllcr}
\hline Site & Latitude (S) & Longitude (E) & Water depth (m) & No of samples \\
\hline 823 & $16^{\circ} 36.98^{\prime}$ & $146^{\circ} 47.05^{\prime}$ & 1638 & 60 \\
819 & $16^{\circ} 37.44^{\prime}$ & $146^{\circ} 19.49^{\prime}$ & 565 & 4 \\
820 & $16^{\circ} 38.22^{\prime}$ & $146^{\circ} 18.23^{\prime}$ & 278 & 6 \\
821 & $16^{\circ} 38.79^{\prime}$ & $146^{\circ} 17.38^{\prime}$ & 213 & 4 \\
824 & $16^{\circ} 26.70^{\prime}$ & $147^{\circ} 45.74^{\prime}$ & 1000 & 3 \\
825 & $16^{\circ} 30.95^{\prime}$ & $148^{\circ} 09.46^{\prime}$ & 939 & 7 \\
588 & $26^{\circ} 06.70^{\prime}$ & $161^{\circ} 13.60^{\prime}$ & 1543 & 40 \\
\hline
\end{tabular}




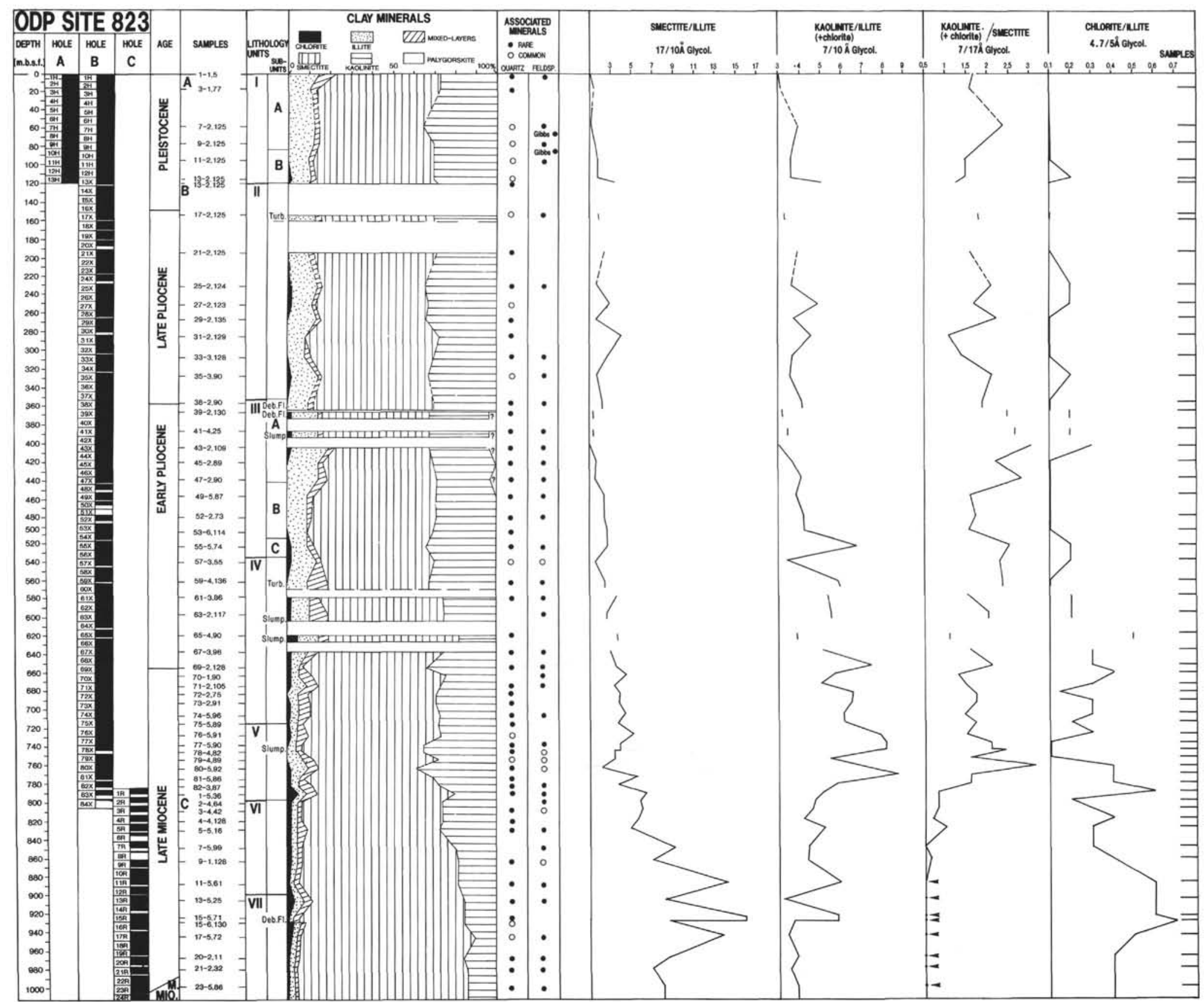


Table 2. Mean distribution of clay minerals and percentage range of main species in the lithologic units of Site 823 .

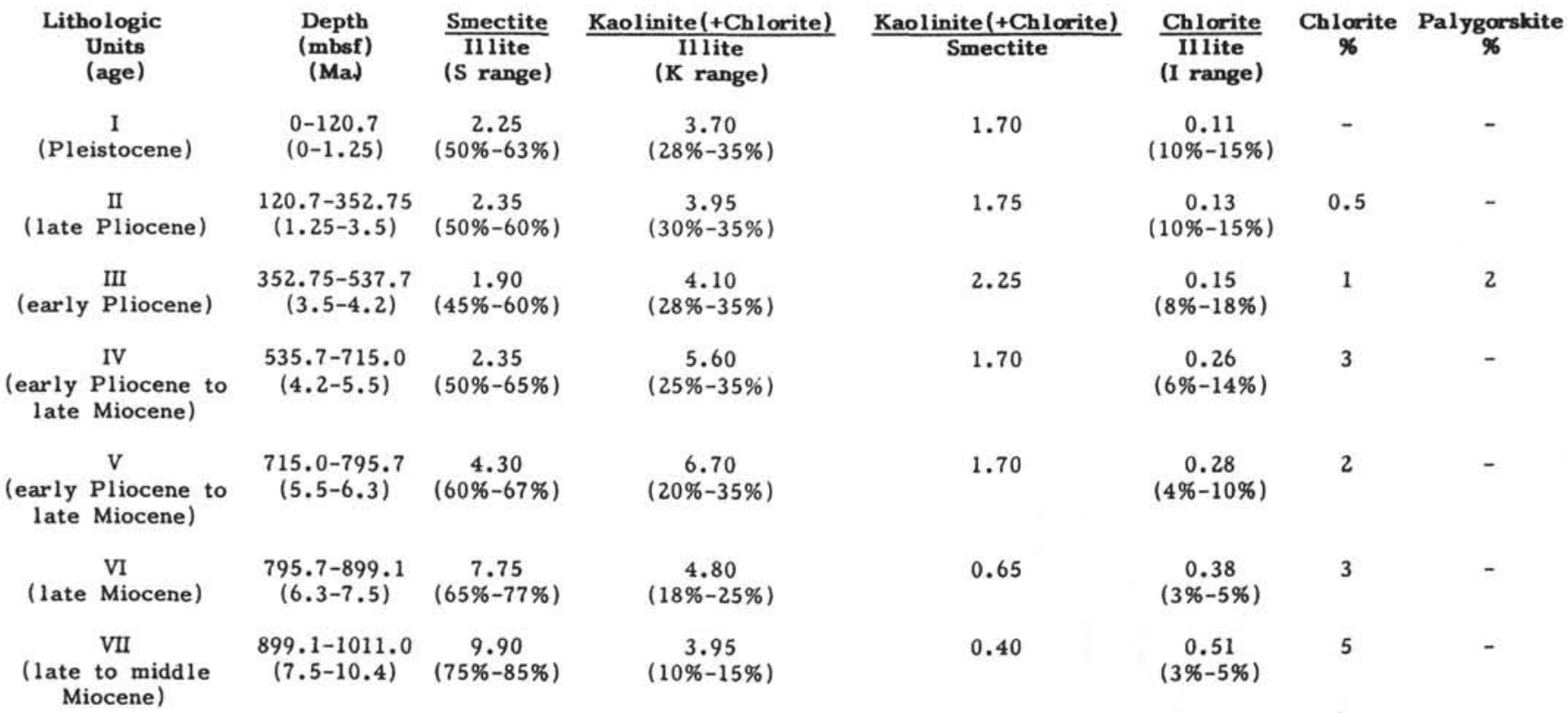

differential settling (e.g., turbidite at Sample 133-823B-59X-4, 136 $\mathrm{cm}$, and surrounding chalks; slumps at 133-823B-63X-2, $117 \mathrm{~cm}$, $-65 X-4,90 \mathrm{~cm},-77 \mathrm{X}-5,90 \mathrm{~cm}$, and surrounding chalk or mixed sediment; and debris flow at $133-823 \mathrm{C}-15 \mathrm{R}-5,71 \mathrm{~cm}$, and surrounding clay/carbonate sediment). The latter situation might correspond to sediments previously stored close to the location of their final redeposition.

\section{Lithostratigraphic Distribution of Clay Mineral Associations}

Seven major lithologic units were distinguished at Site 823, where benthic foraminiferal assemblages indicate deposition during the late Neogene at lower bathyal depths (1000-2000 m; Kate et al., this volume). More than 1800 gravity flows occurred almost contemporaneously with the deposition of the surrounding sediments (Davies, McKenzie, Palmer-Julson, et al., 1991) and are described as follows:

1. Unit 1 (0-120.7 mbsf; Pleistocene): pelagic to hemipelagic ooze interbedded with layers interpreted as turbidites and debris flows.

2. Unit II (120.7-352.75 mbsf; late Pliocene): nannofossil ooze with clay and bioclasts interbedded with lithoclastic rudstones (debris flows) and graded packstones (turbidites).

3. Unit III (352.7-535.7 mbsf; early Pliocene): one subunit containing pelagic to hemipelagic sediments (nannofossil chalk) enclosed between two subunits composed of massive debris flows and surrounded by slumps.

4. Unit IV (535.7-715.0 mbsf; early Pliocene to late Miocene): foraminifer nannofossil chalk with large-scale slump features and variable clay content with accompanying color changes (light to dark greenish-gray).

5. Unit V (715.0-795.7 mbsf; early Pliocene to late Miocene): higher clay content in dark gray nannofossil mixed sediment to nannofossil claystone. Few packstone layers, interpreted as turbidites.

6. Unit VI (795.7-899.1 mbsf; late Miocene): alternations of white to light gray, strongly bioturbated nannofossil chalk to mixed sediments and limestone and clayey, nannofossil chalk with dark greenish-gray nannofossil mixed sediments and claystone. Presence of graded turbidites, microfaults, and large-scale slump folds. Units VI and VII contain about $50 \%$ of the total number of debris flows observed in the sequence at Site 823 .
7. Unit VII (899.1-1011.0 mbsf; late to middle Miocene): shallow-water, platform-derived pebbles and clasts within lithoclastic rudstones, interpreted as debris flows, and interbedded with clay-rich nannofossil mixed sediments (chalk to claystone) as well as with turbiditic sand- to silt-sized layers.

The sedimentation rates are considered to be just over $110 \mathrm{~m} / \mathrm{m}$.y. from 0 to $435 \mathrm{mbsf}, 166 \mathrm{~m} / \mathrm{m}$.y. from 435 to $771 \mathrm{mbsf}$, and less than $10 \mathrm{~m} / \mathrm{m}$.y. near the bottom of the section ( $972-991 \mathrm{mbsf}$ ).

Close associations are evident at Site 823 between the distribution of the average clay-mineral assemblages and the main lithologic units (Fig. 3, Table 2). These results are described from the bottom to the top of the sedimentary column, as follows:

1. Unit VII (1011.0-899.1 mbsf, latest part of middle Miocene to late Miocene, 10.4-7.5 Ma.): Crystalline smectite is abundant (75\% to $85 \%$ of the clay minerals) relative to other species $(\mathrm{S} / \mathrm{I}=9.90$, $\mathrm{K} / \mathrm{S}=0.40$ ). Illite and kaolinite exhibit the lowest amounts of the whole series $(3 \%-5 \%$ and $10 \%-15 \%$, respectively). By contrast, chlorite, despite its low percentage $(5 \%)$, is relatively abundant compared to illite $(\mathrm{C} / \mathrm{I}=0.51)$ and other minerals. Finally, the kaolinite (+ chlorite)/illite ratio in Unit VII is significantly lower than above, in Units VI to IV (K/I = 3.95 in Unit VII, 4.80 to 6.70 in Units VI to IV) and displays values similar to those of Pliocene-Pleistocene Units III to I (4.10 to 3.70$)$.

2. Unit VI (899.1-795.7 mbsf, late Miocene, 7.5-6.3 Ma): Smectite remains abundant but less than in lithologic Unit VII (65\%-77\% and $75 \%-85 \%$, respectively), as indicated by $\mathrm{S} / \mathrm{I}$ and $\mathrm{K} / \mathrm{S}$ mean values ( 7.75 vs. 9.90 and 0.65 vs. 0.40 , respectively). The percentage of kaolinite increases (range $=18 \%-25 \%$ ), that of illite is constant $(3 \%-5 \%)$, and that of chlorite decreases slightly (3\%). The S/I and $\mathrm{C} / \mathrm{I}$ ratios decrease uphole (14-6 and $0.6-0.3$, respectively), whereas the $\mathrm{K} / \mathrm{S}$ ratio increases slightly $(0.4-0.8)$, and the $\mathrm{K} / \mathrm{I}$ ratio is stable (4.5) (Fig. 3). The clay-mineral association in Unit VI is considered to indicate a transition from lithologic Unit VII to V.

3. Unit V (795.7-715.0 mbsf, late Miocene to early Pliocene, 6.3-5.5 Ma): The clay-mineral association shows a further decrease of smectite contents, but less than in Unit VI (from $67 \%$ to $60 \%$, instead of from $77 \%$ to $65 \%$ ). The maximum percentages of smectite are similar in Unit V and in overlying Units IV to I. To the contrary, 
maximum amounts of kaolinite $(35 \%)$ are not exceeded in overlying units, with the minimum values continuing to increase uphole (Table 2$)$. The illite percentages increase somewhat ( $4 \%-10 \%)$, but are less than kaolinite contents, which determine maximum values of the $\mathrm{K} / \mathrm{I}$ ratio (Fig. 3). The chlorite/illite ratio continues to decrease significantly (mean 0.38 to 0.28 when passing from Unit VI to Unit V). Clay-mineral characteristics in Unit V represent the final step in the transition between Miocene and Pliocene-Pleistocene assemblages.

4. Unit IV (715.0-535.7 mbsf, late Miocene to early Pliocene, 5.5-4.2 Ma): the minimum percentages of smectite continue to decrease (from $60 \%$ to $50 \%$ ), while those of kaolinite increase ( $20 \%$ $25 \%$ ). However, maximum percentages of both minerals remain fairly stable, whereas amounts of crystalline illite still increase (from $4 \%-$ $10 \%$ to $6 \%-14 \%$ ). In Unit IV, this determines a stable K/S ratio, and by contrast, significantly decreasing $\mathrm{S} / \mathrm{I}$ and especially $\mathrm{K} / \mathrm{I}$ ratios (Fig. 3, Table 2). Chlorite increases slightly (mean 3\%) together with illite, determining the unchanging $C / I$ values $(0.28-0.26)$. Random mixed-layer clays show their highest amounts of the whole series $(5 \%-10 \%)$ and are dominated by chlorite-smectite types.

5. Unit III (535.7-352.75 mbsf, early Pliocene, 4.2-3.5 Ma): Smectite values in Unit III display in some levels the lowest amounts of the entire Site 823 series (45\%). Illite values exhibit highest amounts (18\%), determining the lowest S/I ratios (mean 1.90) and low K/I ratios (mean 4.10). Minimum contents of kaolinite in this unit are slightly higher than those in Unit IV ( $28 \%$ instead of $25 \%)$, and the average $\mathrm{K} / \mathrm{S}$ ratio is the highest recorded at Site 823 (2.25, Table 2). Chlorite is present in trace amounts only (mean $1 \%$ ), especially in Subunits IIIC and IIIA, which are characterized by massive debris flows and slumps. Palygorskite occurs only locally (mean $2 \%$ ) in Subunit IIIA, where redeposited sediments are abundant.

6. Unit II (352.75-120.7 mbsf, late Pliocene, 3.5-1.25 Ma.); and Unit I (120.7-0 mbsf, Pleistocene, 1.25-0 Ma): Clay associations in lithologic Units II and I are similar and marked by fairly abundant kaolinite $(10 \%-15 \%)$ and illite $(28 \%-35 \%)$, abundant smectite $(50 \%$ $63 \%$ ), rare mixed-layer clays (trace amounts to $5 \%$ ), and scattered trace amounts of chlorite (Fig. 3, Table 2). Only few mineralogical differences are seen with Unit III, Units II and I being characterized by a slightly increased $\mathrm{S} / \mathrm{I}$ ratio and slightly decreased $\mathrm{K} / \mathrm{I}$ and $\mathrm{K} / \mathrm{S}$ ratios only. The K/I ratio displays its lowest values at Site 823 (mean 3.70 in Unit I; 3.95 in Unit II; 4.10 in Unit III; and 5.60 in Unit IV). The only clay-mineral difference observed in Unit I relative to Unit II consists of a lower variability of the indices measured (e.g., S/I, K/I, C/I. Fig. 2).

Clay-mineral associations in shallowly buried calcareous deposits of Quaternary age, sampled during Leg 133 along the west-east transect of drill sites off eastern Australia show only minor differences (Fig. 2, Table 3). This probably results from the large dispersal properties of clay minerals in the marine environment. Minor differences registered in Pleistocene sediments from the Australian margin and the Queensland Trough probably result from stratigraphic differences or settling conditions controlled by local hydrodynamics. The easternmost Sites 824 and 825 (located on the Queensland Plateau) are characterized by the presence of small amounts of palygorskite, which might constitute a marker of eastern sources (i.e., carbonate banks). The abundance of smectite at Site 825 on Holmes Reef is similar to those in Miocene sediments at Site 823 in the Queensland Trough.

\section{INTERPRETATION OF CLAY-MINERAL SUCCESSIONS AT SITE 823}

Clay assemblages display only minor qualitative and quantitative variations that might be related to the depth of burial. No progressive evolution of clay mineral abundances was seen with increasing depth along the 1011-m-thick sedimentary column (Fig. 3). At Site 823, no downhole increases can be seen in the percentage of illite, a mineral favored by diagenetic alteration resulting from increasing depth of burial (Kisch, 1983). Moreover smectite, which is very sensitive to diagenetic alteration by increasing temperature and lithostatic pres- sure, shows higher abundances in the hemipelagic chalks of lithologic Units VI and VII in the lower part of Hole 823C (Fig. 3). These results suggest the absence of any significant diagenetic alteration of clays with increasing depth of burial. This hypothesis is supported by the low temperatures recorded all along the holes at Site 823, where the maximum values recorded are $37^{\circ}$ and $41^{\circ} \mathrm{C}$ (Davies, McKenzie, Palmer-Julson, et al., 1991). This conclusion is in accord with other studies of clay-mineral assemblages in sedimentary series less than $2 \mathrm{~km}$ thick and located in areas marked by low-to-moderate geothermal gradients (e.g., Kisch, 1983).

The absence at Site 823 of clay diagenesis in relation to increasing depth of burial implies that clay mineral assemblages primarily reflect detrital influx from adjacent continents. The qualitative and quantitative variations of clay associations at Site 823 were essentially controlled by environmental conditions on exposed landmasses and the mechanisms of transport. Generally speaking, illite and chlorite mostly derive from the erosion of crystalline and ancient sedimentary rocks; kaolinite was often reworked from surficial soils developed in warm, humid areas with drainage; crystalline smectite mainly formed in surficial formations (soils, sediments) where chemical elements supplied by run-off concentrate under seasonally dry conditions; and random mixed-layer clays represent complex transitional minerals formed in various surficial environments, namely during weathering (e.g., Millot, 1970). Of course, all soil-derived clay-mineral groups can be either eroded from weathering formations and then rapidly deposited in the ocean, or reworked from paleosoils and ancient rocks and sediments where they were previously stored. The changes in clay-mineral stratigraphy thus reflect paleoenvironmental evolution (e.g., Chamley, 1989; Weaver, 1989).

The major change in the clay mineral succession, which consists of a late Miocene decrease of the smectite abundance associated with increases of kaolinite and illite, mainly results from the global Cenozoic cooling associated with an intensified polar glaciation (Kennett, $1977,1986)$. This cooling increasingly favored physical weathering relative to chemical weathering, and the subsequent reworking of rock-derived minerals such as illite (e.g., Chamley, 1989). The increase of kaolinite may have resulted from either more humid conditions on land and intensified hydrolysis processes in warm northern Australia or the reworking of old kaolinite-rich pedogenic blankets.

\section{Middle to Late Miocene (10.4-7.5 Ma)}

Lithologic Unit VII contains abundant redeposited sediments, probably reworked from the Australian continental platform and slope during an interval of low sea level (Davies, McKenzie, Palmer-Julson, et al., 1991). Low sea levels could have favored transport of abundant clayey, terrigenous sediments, as a result of increased continental erosion. These sediments normally include a clay fraction especially enriched in illite and chlorite eroded from geological substrates. However, this is not the case for Site 823, where Unit VII displays the highest amounts of smectite of the whole series (Fig. 2, Table 2), even in some redeposited facies (e.g., debris flows in Section 133-823C$15 \mathrm{R}-5$, at $71 \mathrm{~cm}$ ). Oxygen isotope data indicate relatively warm climatic conditions on the Lord Howe Rise off eastern Australia during the late Miocene, especially from about 9 to $6.5 \mathrm{Ma}$ (Kennett and Von der Borch, 1985). Relative warmth probably favored the development of smectite in deeply weathered soils of Queensland and adjacent areas. The effects of late Cenozoic climate would have prevailed over the effects of variations of sea level and uplift of the continental margin. Significant amounts of chlorite (see C/I ratio), a mineral less easily transported over great distance than smectite, might indicate some reworking from the margin to the Queensland Trough.

\section{Late Miocene (7.5-6.3 Ma.)}

Unit VI corresponds to a major transitional period at Site 823. The number of redeposited layers and their thickness are still important 


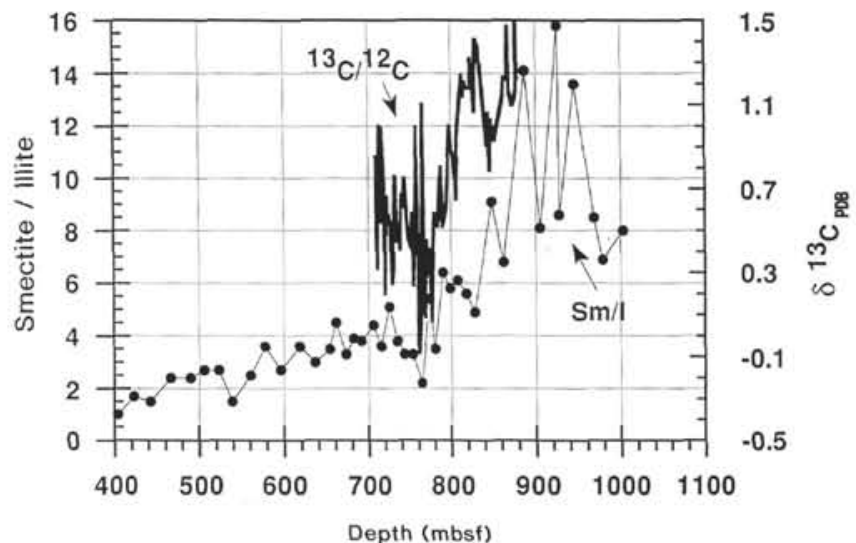

Figure 4. Comparison of the smectite/illite ratio decrease and the negative carbon shift (Chron C3 AR) in upper Miocene sediments at Site 823.

but decrease upward. A jerky decrease of smectite percentages is balanced by an increase of kaolinite amounts principally (Fig. 3, Table 2). As in Unit VII, clay-mineral variations in Unit VI cannot be directly related to a change in sea level. A rise of the sea level would have resulted in decreased erosion and better development of soils, especially of smectite-bearing soils (see Chamley, 1989). Simultaneously, the contents of rock-derived illite would have decreased, especially during the sea-level rise envisaged from 7.5 to $6.3 \mathrm{Ma}$ by Haq et al. (1987). Such a decrease of illite is not registered in the clay-mineral succession. Moreover the mineralogical change observed is not restricted within the limits of the sea-level change reported in the literature, but marks the beginning of a long-term trend that persisted until the Pleistocene. As a consequence, the increase of kaolinite contents and inferred decrease of smectite in lithologic Unit VI probably results from an increase in continental rainfall favoring the formation of kaolinitic soils, rather than from a change in sea level. Notice that this major shift in clay-mineral assemblage is closely associated between 880 and $710 \mathrm{mbsf}(6.5-5.9 \mathrm{Ma})$ with a general decrease in the $\delta^{13} \mathrm{C}$ from about $1.17 \%$ to less than $0.39 \%$ (Fig. 4). The carbon shift, which is generally considered to have been caused by a transfer of light continentally derived carbon $\left({ }^{12} \mathrm{C}\right)(\mathrm{e} . \mathrm{g}$., Müller et al., 1991), could be partly a consequence of increased precipitation and terrestrial discharge.

\section{Late Miocene to Earliest Pliocene (ca. 6.3-5.5 Ma)}

Unit $\mathrm{V}$ is characterized by abundant terrigenous clay particles, but only a few redeposition facies (slumps). Clay-mineral variations are smaller than in the underlying Unit VI and mainly correspond to the end of the major smectite shift that started at a depth of about $900 \mathrm{~m}$ (i.e., ca. 7.5 Ma). This decrease of smectite percentages was balanced by higher contents of kaolinite and significant increases of illite (Fig. 3). The concomitant increase of kaolinite and illite suggests erosion and reworking of both soils and rocky substrates on the adjacent Australian continent. This may reflect precipitation along the northeastern Australian margin, which led to the development of kaolinitic soils at a time when uplift of the eastern highlands and Australian margin (Plumb, 1979; Davies, McKenzie, Palmer-Julson, et al., 1991) favored the mixed erosion of soils and substrates by running waters. As a consequence, regional effects tend to be better expressed in Unit $\mathrm{V}$ than in underlying units.

\section{Latest Miocene to Early Pliocene (ca. 5.5-4.2 Ma)}

Lithologic Unit IV is characterized by numerous, episodic alternations of clay-rich and carbonate-rich sediments, with increased abundance of redeposition facies, which may be related to sea-level fluctu- ations or pulses in the uplift of the Australian margin. Clay-mineral assemblages display only minor variations, probably because of relatively stable climate. The major mineralogical change consists of a last and noticeable increase of illite that is associated with slightly increased chlorite, with kaolinite being stable (Fig. 3). This peculiar change suggests increased erosion of old rocky substrates to provide illite and chlorite, relative to kaolinite-bearing surficial soils (e.g., Chamley, 1989). The cause might be, in addition to the world climatic cooling, the continuation of uplift on the eastern Australian margin that probably persisted during the early Pliocene (Davies, McKenzie, Palmer-Julson, et al., 1991). An additional argument is provided by the presence in Unit IV of the maximum amounts of random mixed layers (up to $10 \%$ of clay minerals; Fig. 3), a group of transitional minerals that often expresses incomplete weathering processes of substrate because of active tectonic activity and relief rejuvenation. Unit IV thus appears to reflect both global and regional environmental changes.

\section{Early Pliocene (4.2-3.5 Ma.)}

Unit III generally consists of hemipelagic nannofossil chalk (Subunit IIIB) interbedded between two subunits (IIIC and IIIA) enriched in redeposited facies that can be correlated to low sea-level stages. In this unit, smectite displays its lowest minimum values of the entire series (see S/I and K/S ratios; Fig. 3, Table 2), whereas illite maximum values are the highest. This is especially the case in reworked facies of Subunits IIIC and IIIA. In addition, chlorite occurs as trace amounts in Subunits IIIC and IIIA, whereas it is absent in the hemipelagic Subunit IIIB (Fig. 3). These slight variations in the clay-mineral distribution probably result from differential settling or reworking processes. The deposition of smectite was favored in the Queensland Trough, a distal basinal environment where its relative accumulation was easier (Subunit IIIB). By contrast, illite, kaolinite, and chlorite were preferentially deposited under the more proximal and hydrodynamically active conditions that prevailed on the Australian margin and were especially supplied to the basin by reworking mechanisms during intervals of low sea level (Subunits IIIC and IIIA). Notice that the presence of palygorskite in the carbonate-rich Subunit IIIA might reflect a preferential supply of materials that have been reworked from calcareous banks located to the east on the Queensland Plateau, where this fibrous clay mineral has been identified at Sites 824 and 825 (Table 3). As in Unit IV, the clay sedimentation in Unit III, therefore, seems to reflect local environmental changes also.

\section{Late Pliocene and Pleistocene (3.5-0 Ma.)}

Lithologic Units II and I contain similar clay assemblages. The clay-mineral record differs from that of Unit III by slightly increased percentages of smectite (Fig. 3, Table 2; see S/I and K/S ratios), perhaps indicative of more distal depositional conditions (i.e., preferential settling of smectite in a quiet environment). The kaolinite/illite ratios display minimum values, probably indicative of the physical weathering conditions that prevailed in latest Cenozoic time. The only noticeable differences between Units II and I consist of the higher mineralogical variability and the local presence of trace amounts of chlorite in the oldest Pliocene unit. As redeposited facies are also more abundant in Unit II than in Unit I, these differences may express local variations in depositional processes (e.g., chlorite-bearing and kaolinite-enriched sediments preferentially reworked from the continental margin during the Pliocene and the Pleistocene). The latest Neogene and Quaternary clay successions mainly express local variations of the environment.

\section{COMPARISON OF CLAY MINERAL DATA BETWEEN SITES 823 AND 588}

Mineralogical study of the fine terrigenous fraction at both Sites 823 (Queensland Trough) and 588 (Lord Howe Rise) provides 
Table 3. Clay mineralogy of selected surficial samples of a west-east transect off northeastern Australia (Leg 133).

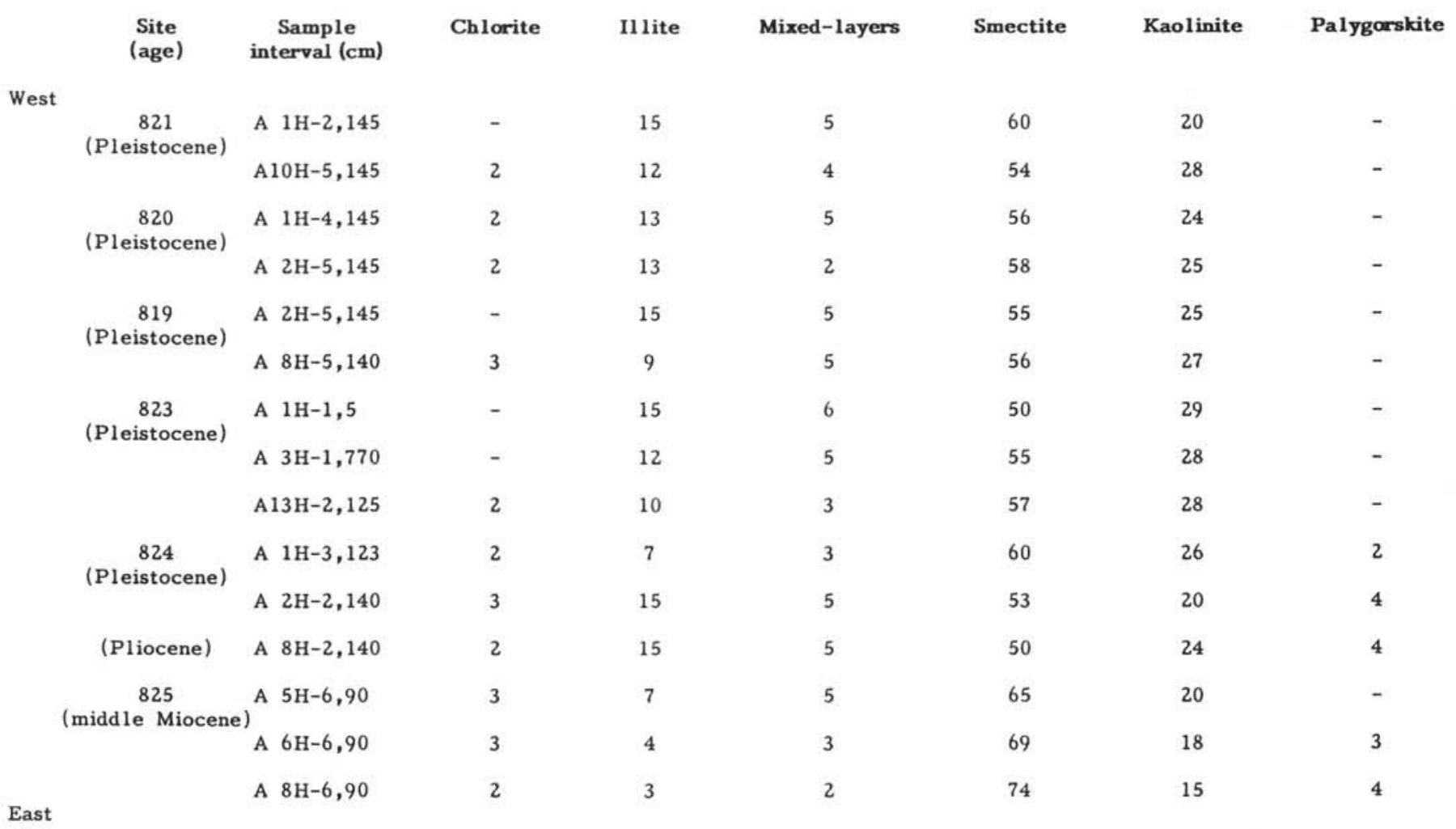

$\mathrm{S}=$ smectite $\mathrm{K}=$ kaolinite $\mathrm{I}=$ illite.

information about weathering and erosion conditions in their respective source areas (Fig. 5). Comparison of data from both sites allows one to reconstruct the evolution of northeastern Australian climate through the Neogene.

Clay-mineral associations in late Miocene to Quaternary age sediments at Site 588 closely resemble those at Site 823 . Dominant smectite $(40 \%-85 \%)$ is associated with kaolinite $(10 \%-30 \%)$, illite $(5 \%-25 \%)$, random mixed-layer clays (trace amounts to $10 \%$ ), and episodic traces of chlorite (Stein and Robert, 1985). A significant clay-mineral variation occurs in upper Miocene deposits above Core 90-588-17, where the mean abundance of kaolinite increases by about $10 \%$.

Near the middle-late Miocene transition (ca. $10 \mathrm{Ma}$ ), only minor differences of clay-mineral indexes were evidenced between both sites, suggesting that clay-mineral associations originated from areas characterized by almost similar weathering conditions. Higher $\mathrm{S} / \mathrm{I}$ and lower K/S values than those in Quaternary deposits indicate that smectitic soils and inferred climatic conditions (i.e., warm temperatures and alternating wet and arid seasons) were probably widely distributed during the middle to late Miocene. Increased illite contents at Site 588 after $11 \mathrm{Ma}$ occurred contemporaneously with an increase in the $\delta^{18} \mathrm{O}$ of benthic foraminifers, which led to some of the highest values of the Miocene sequences. This isotopic trend has been interpreted as the consequence of ice development on Antarctica and/or cooler temperatures of sea water (Kennett and Von der Borch, 1985). It is likely that those environmental changes were linked to some aridification in Australia and/or increased influence of westerly winds.

During the middle late Miocene at Site 823, near the Unit VII/Unit VI passage, values of $\mathrm{S} / \mathrm{I}$ and $\mathrm{K} / \mathrm{I}$ indexes higher than near the middle late Miocene transition suggest that continental weathering increased significantly in the source areas, at $16^{\circ}$ to $17^{\circ} \mathrm{S}$. This occurred during a period of relative warmth, which has been deduced from slightly lower values of the $\delta^{18} \mathrm{O}$ at several DSDP sites on Lord
Howe Rise (Kennett and Von der Borch, 1985), and also from calcareous nannoplankton biogeography in the Atlantic Ocean (Haq, 1980). However, the persistence of a decreasing trend of both $\mathrm{S} / \mathrm{I}$ and $\mathrm{K} / \mathrm{I}$ indexes at Site 588 suggests that the intensity of this warming was insufficient to reverse aridification processes in central Australia.

The S/I index at Site 823 decreased sharply in upper Miocene sediments after 7.0 Ma. (lithologic Units VI and V). This was followed by increasing values of both $\mathrm{K} / \mathrm{I}$ and $\mathrm{K} / \mathrm{S}$ indexes, which culminated from 6.0 to 5.5 Ma. Development of kaolinite at the expense of smectite and illite at $16^{\circ} \mathrm{S}$ most probably indicates intensification of precipitation along the northeastern Australian margin. A co-eval increase of both indexes $\mathrm{K} / \mathrm{S}$ and $\mathrm{K} / \mathrm{I}$ at Sites 588 suggests that intensified precipitation and/or southward transport of kaolinite extended toward mid-latitudes. Relatively important humidity persisted on the northeastern Australian margin until Quaternary time, a further maximum of precipitation being deduced from high $\mathrm{K} / \mathrm{S}$ values at about $3.5 \mathrm{Ma}$.

The S/I index at Site 588 reached its lowest values of the entire late Neogene at about $6.0 \mathrm{Ma}$. These indicate maximum aridity in central Australia and/or maximum influence of the westerlies, co-eval with desiccation of lacustrine environments in southeastern Australia (Bowler, 1982). A long-term, decreasing trend of the S/I index at Site 823 culminated at $3.5 \mathrm{Ma}$, probably in relation to northward expansion of desert areas in central Australia and/or development of the westerly wind circulation, during the late Neogene. Clay-mineral associations at Sites 588 and 823 indicate accentuated climatic contrasts in northeastern Australia during the late Neogene, marked by the progression of aridity in the central deserts (and increased influence of the westerlies) and enhanced precipitation on the northeastern continental margin. This evolution began at about $7.0 \mathrm{Ma}$ and reached a maximum at the beginning of the Messinian, at about $6.0 \mathrm{Ma}$. Since then, the long-term trend of continental climate in northeastern Australia has not changed significantly. 


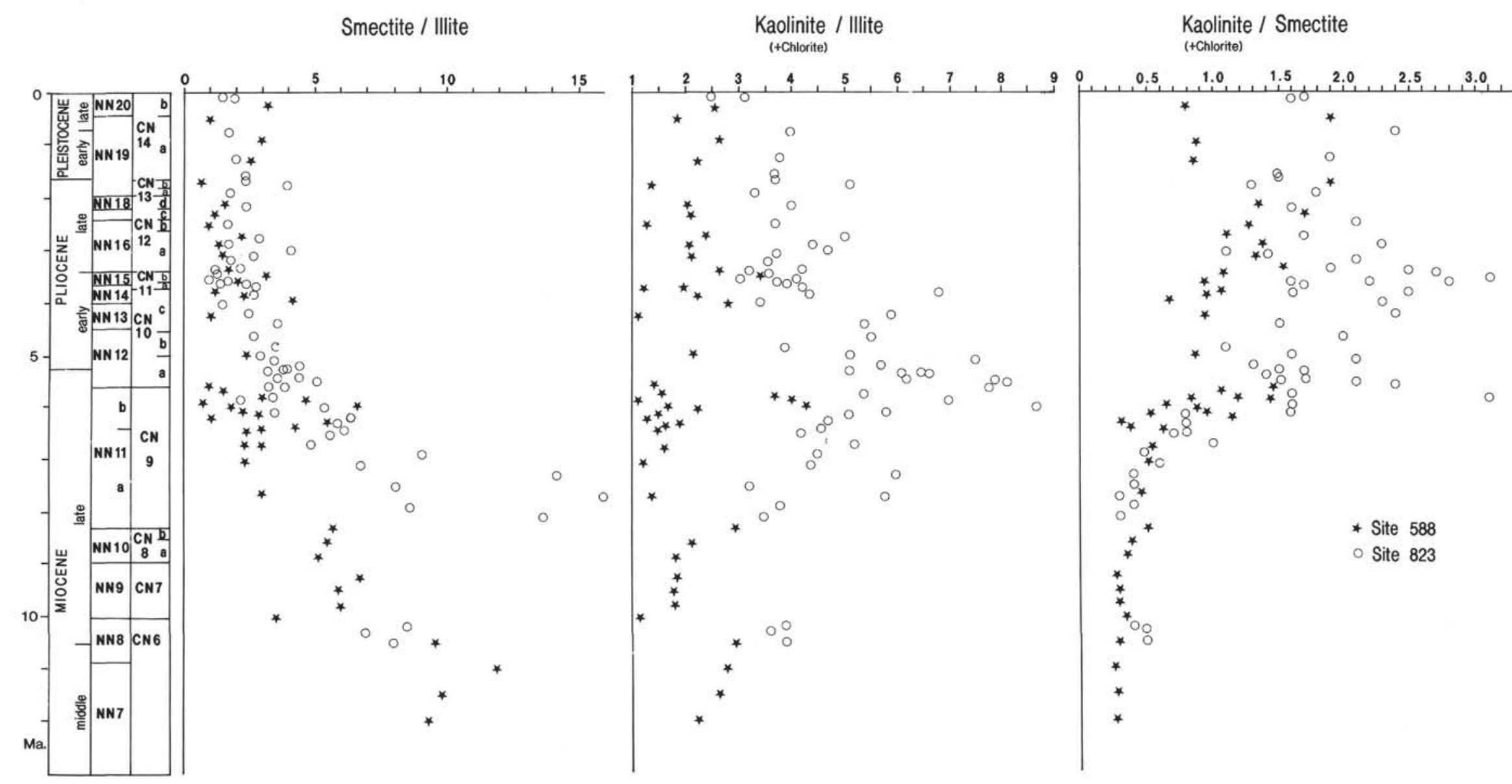

Figure 5. Clay-mineral ratios in upper Cenozoic sediments of Sites 823 and 588, east of Australia. 


\section{CONCLUSIONS}

1. A diversified clay-mineral assemblage dominated by smectite, kaolinite, and illite occurs at Site 123 off northeastern Australia in a 1011-m-thick, discontinued series of pelagic sediments alternating with turbidites. The absence of any clay-mineral variation directly correlated with the depth of burial, or closely related to lithologic changes, stresses the absence of any significant diagenetic influence upon clay-mineral associations, which mostly express paleoenvironmental evolution in their source areas.

2. A major decrease of smectite abundance beginning near $7.0 \mathrm{Ma}$ during the late Miocene has been balanced by increasing contents of kaolinite and illite. This is essentially a consequence of evolving weathering conditions and climatic processes in Australia, in relation to cooling and glaciation at high latitudes. Improved drainage conditions associated with uplift of the eastern highlands, and preferential erosion of upstream areas of the drainage basins, may have regionally influenced the kaolinite and illite contents of the clay assemblages.

3. From $7.5 \mathrm{Ma}$ onward, decreased formation of smectitic soils and increased erosion of illite-bearing substrate rocks resulted from the development of aridity in the Australian continental interior. Concomitant development of kaolinitic soils in northeastern Australia is attributed to increased rainfall principally, although uplift of the Australian margin and a sea-level rise may have influenced positively the kaolinite genesis. During the Pliocene-Pleistocene after 4.2 Ma, only minor variations occur in the clay associations; these mainly concern the presence of chlorite and palygorskite, generally associated with turbidites, slumps, or debris-flow deposits that have been reworked from shallow-water areas. The upper part of the series therefore has been dominantly influenced by local environmental evolution. The clay-mineral fluxes identified at $16^{\circ} \mathrm{S}$ on a west-east transect extending from the Australian margin to the Queensland Plateau are almost constant during the Pleistocene. They characterize essentially the Australian sources, and possibly an additional supply of palygorskite-bearing material that has been reworked from the carbonate banks located to the east on the Queensland Plateau.

4. Clay-mineral records at Site $823\left(16^{\circ} \mathrm{S}\right)$ and at Site 588 drilled at $26^{\circ} \mathrm{S}$ on Lord Howe Rise generally show similar trends. Increased contents of kaolinite relative to smectite after $7.0 \mathrm{Ma}$ are co-eval at both sites, but smaller values at Site 588 suggest a southward decrease of humidity and possibly a slighter influence of the eastern highlands uplift. Periods of maximum humidity are evidenced from 6.0 to $5.5 \mathrm{Ma}$ and at about $3.5 \mathrm{Ma}$. Concomitant increases of humidity on continental borders, and of aridity in the continental interior, emphasize the contrasts of climate in Australia and constitute important stages in the evolution toward modern climatic conditions.

\section{ACKNOWLEDGMENTS}

This work was supported by ODPFrance. Helpful discussions and detailed reviews considerably improved the manuscript. J.P. Kennett, A. Monaco, and S. Stewart are especially acknowledged. The technical support was provided by M. Bouquet, F. Dujardin, and P. Récourt.

\section{REFERENCES}

Berger, W.H., and Vincent, E., 1986. Deep-sea carbonates: reading the carbonisotope signal. Geol. Rundsch., 75:249-269.

Bowler, J.M., 1982. Aridity in the late Tertiary and Quaternary of Australia. In Barker, W.R., and Greenslade, P.J.M. (Eds.), Evolution of the Flora and Fauna of Arid Australia: Sydney (Peacock), 35-45.
Chamley, H., 1989. Clay Sedimentology: Heidelberg (Springer Verlag).

Chamley, H., and Debrabant, P., 1984. Mineralogical and geochemical investigations of sediments on the Mazagan Plateau, northwestern African margin (Leg 79, Deep Sea Drilling Project). In Hinz, K., Winterer, E.L., et al., Init. Repts., DSDP, 79: Washington (U.S. Govt. Printing Office), 497-503.

Davies, P.J., McKenzie, J.A., Palmer-Julson, A., et al., 1991. Proc. ODP, Init. Repts., 133: College Station, TX (Ocean Drilling Program).

Flenley, J., 1981. The Equatorial Rain Forest: A Geological History: London (Butterworths).

Gibbs, R.J., 1977. Clay mineral segregation in the marine environment. $J$. Sediment. Petrol., 47:237-243.

Glasby, G.P., 1971. The influence of aeolian transport of dust particles on marine sedimentation in the Southwest Pacific. J. R. Soc. N.Z., 1:285-300.

Griffin, J.J., Windom, H., and Goldberg, E.D., 1968. The distribution of clay minerals in the World Ocean. Deep-Sea Res. Part A, 15:433-459.

Haq, B.U., 1980. Biogeographic history of Miocene calcareous nannoplankton and paleoceanography of the Atlantic Ocean. Micropaleontology, 26:414-443.

Haq, B.U., Hardenbol, J., and Vail, P.R., 1987. Chronology of fluctuating sea levels since the Triassic. Science, 235:1156-1167.

Holtzapffel, T., 1985. Les minéraux argileux. Préparation-Analyse diffractométrique et détermination. Soc. Geol. Nord, 12:136.

Kennett, J.P., 1977. Cenozoic evolution of Antarctic glaciation, the circumAntarctic Ocean, and their impact on global paleoceanography. J. Geophys. Res., 82:3843-3860.

1986. Miocene to early Pliocene oxygen and carbon isotope stratigraphy of the Southwest Pacific, DSDP Leg 90. In Kennett, J.P., von der Borch, C.C., et al., Init. Repts. DSDP, 90 (Pt. 2): Washington (U.S. Govt. Printing Office), 1383-1411.

Kennett, J.P., and von der Borch, C.C., 1986. Southwest Pacific Cenozoic paleoceanography. In Kennett, J.P., von der Borch, C.C., et al., Init. Repts. DSDP, 90: Washington (U.S. Govt. Printing Office), 1493-1517.

Kisch, H.J., 1983. Mineralogy and petrology of burial diagenesis (burial metamorphism) and incipient metamorphism in clastic rocks. In Larsen, G., Chilingar, G.V. (Eds.), Diagenesis in Sediments and Sedimentary Rocks (Vol. 2). Amsterdam (Elsevier), Dev. in Sedimentol. Ser., 25B:289-493.

McCrea, J.M., 1950. Isotopic chemistry of carbonates and a paleotemperature scale. J. Chem. Phys., 18:849-857.

Millot, G., 1970. Geology of Clays: Heidelberg (Springer-Verlag).

Müller, D.W., Hodell, D.A., and Ciesielski, P.F., 1991. Late Miocene to earliest Pliocene (9.8-4.5 Ma) Paleoceanography of the subantarctic Southeast Atlantic: stable isotopic, sedimentologic, and microfossil evidence. In Ciesielski, P.F., Kristoffersen, Y., et al., Proc. ODP, Sci. Results, 114: College Station, TX (Ocean Drilling Program), 459-474.

Pédro, G., 1984. La genèse des argiles pédologiques, ses implications minéralogiques, physico-chimiques et hydriques. Sci. Geol. Bull., 37:333-347.

Plumb, K.A., 1979. The tectonic evolution of Australia. Earth Sci. Rev., $14: 205-249$.

Stein, R., and Robert, C., 1985. Siliciclastic sediments at Sites 588, 590 and 591: Neogene and Paleogene evolution in the Southwest Pacific and Australian climate. In Kennett, J.P., von der Borch, C.C., et al., Init. Repts. DSDP, 90: Washington (U.S. Govt. Printing Office), 1437-1455.

Walter, H., 1971. Ecology of Tropical and Subtropical Vegetation: Edinburgh (Oliver and Boyd).

Weaver, C.E., 1989. Clays, Muds, and Shales: New York (Elsevier), Dev. in Sedimentol. Ser., 44.

\footnotetext{
"Abbreviations for names of organizations and publications in ODP reference lists follow the style given in Chemical Abstracts Service Source Index (published by American Chemical Society).
}

\section{Ms 133SR-247}

Date of initial receipt: 23 March 1992

Date of acceptance: 13 October 1992 